\title{
Does climate influence phenological trends in social wasps (Hymenoptera: Vespinae) in Poland?
}

\author{
Piotr TRYJANOWSKI ${ }^{1}$, TADEUSZ PAWLIKOWSKI ${ }^{2}$, KRZYSZTOF PAWLIKOWSKI $^{3}$, WeroniKa \\ BANASZAK-CIBICKA ${ }^{1}$ and TIM H. SPARKS ${ }^{1 *}$
}

\author{
${ }^{1}$ Institute of Zoology, Poznań University of Life Science, Wojska Polskiego 71C, 60-625 Poznań, Poland \\ ${ }^{2}$ Institute of Ecology \& Environmental Protection, Copernicus University, 9 Gagarina Str., 87-100 Toruń, Poland \\ ${ }^{3}$ Sea Fisheries Institute in Gdynia, Department of Fisheries Oceanography and Marine Ecology, 1 Kołłątaja Str., 81-332 Gdynia, \\ Poland
}

Key words. Hymenoptera, Vespinae, Vespa crabro, Vespula germanica, German wasp, hornet, appearance date, climate change, long-term study, temperature, social insects, Poland

\begin{abstract}
Responses of insects to recent climate change have been well documented in a number of taxa, but not in wasps. This study examined shifts in phenology of the two most important wasp species (Vespa crabro and Vespula germanica) in Poland over the last three decades. Both species showed similar temporal trends, advancing their phenology after the early 1980s, but this pattern was detected only for workers not for the appearance of queens. The appearance times for $V$. germanica were negatively related to mean April temperature, appearing earlier in years with warmer springs, and positively related to precipitation in April. The studied species advanced aspects of their phenology, but linking this to temperature was not achieved for $V$. crabro suggesting that we have to pay more attention to the life history traits of the study organisms.
\end{abstract}

\section{INTRODUCTION}

Recent climate changes have influenced many living organisms, including the phenology, population size, and migration and distribution patterns of insects (e.g. Warren et al., 2001; Bale et al., 2002; Konvicka et al., 2003; Dell et al., 2005, Sparks et al., 2007). This is likely to be both an indirect effect, because local trends in temperatures affect plants which as the main food source of many phytophagous insects influence their activity, and a direct effect, since increasing temperature affects insect metabolism and activity per se. To date, researchers have focussed mainly on charismatic species, like butterflies and dragonflies, where a lot of data were collected, often by amateurs (e.g. Roy \& Sparks, 2000; Gordo \& Sanz, 2006; Hassall et al., 2007; Doi, 2008). Coinciding with this were publications on species of a general economic (and ecological) importance (Gordo \& Sanz, 2006; Harrington et al., 2007; Le Conte \& Navajas, 2008). Among potentially interesting species are social wasps, predators of other insects, mainly dipterans, and which occupy both rural and urban habitats (Edwards, 1980; Matsuura \& Yamane, 1984; Pawlikowski, 1990). They also eat a variety of carbohydrate-based food (nectar, honey, honeydew, plant juice). In the quest for food, they often visit flowers of Umbelliferae, Scrophulariaceae and thickets of Symphoricarpos albus, as well as foraging in human habitation where products or food scraps are subjected to ethyl fermentation. When foraging they are not only pollinators, but also vectors of pathogenic microorganisms. Thus they may constitute a sanitary threat (Nadolski et al., 2000). At the same time, because of their activeness and aggressiveness, wasps pose a high allergological and toxicological threat to humans (Nadolski et al., 2000; Mauss, 2008).

In our study area in central Poland, the two study species Vespula germanica (Fabricius, 1793) and Vespa crabro (Linnaeus, 1758) are of special interest (Pawlikowski, 1990; Pawlikowski \& Pawlikowski, 2006). V. germanica is the most common species (from $86 \%$ to more than $90 \%$ of the total specimens) and $V$. crabro (up to only $1 \%$ of the total specimens) is an important charismatic species. $V$. germanica is a social wasp species, native to the Palaearctic region: Europe, North Africa and temperate regions of Asia (Spradbery \& Maywald, 1992). Its nests are usually subterranean, but they may be aerial or built in roofs, attics, and within the walls of houses (Spradbery, 1973). In urban areas $30 \%$ of nests are located in buildings, while in rural or forested areas up to $100 \%$ of nests are found underground (Moller et al., 1991). The nest may reach a diameter of $30 \mathrm{~cm}$ and contain more than 10,000 individuals. Fordham et al. (1991) found that urban nests produced more workers and reproductive progeny. Fertilized queens overwinter in a sheltered place. They start to emerge around mid-March. Workers appear later and, if the climate is not too rigorous, continue to forage until mid-November.

The other originally Palaearctic species, V. crabro, is the largest European eusocial wasp. The female measures 25 to $35 \mathrm{~mm}$ long, males and workers are smaller. $V$. crabro is primarily a forest insect and it typically builds

\footnotetext{
* Corresponding author: thsparks@btopenworld.com
} 
its nests in hollow trees. Nests are also found in thatched roofs, barns, attics, hollow walls of houses, and abandoned beehives. While impressive due to their size and loudness, European hornets are in fact much less aggressive than $V$. germanica. While not aggressive when encountered far from the nest, multiple workers will vigorously defend the nest if provoked. As for all wasps, the colonies die out in winter. Only fertilized females overwinter, founding new colonies close to their winter shelter. Queens appear from mid-April, workers are active until mid-October.

As was mentioned earlier, $V$. germanica and $V$. crabro have a range of potential economic and health impacts. The wasps make holes in ripe fruit to obtain sugar, scrape off the tender bark of young trees to obtain construction material and sugary sap. In summer and autumn, they can raid beehives and enters dwellings in the search for sugary foodstuffs for nourishment and for meat to feed the larvae. European wasps are also great scavengers and are usually found around areas of human habitation and activity. This is why they can be a major social pest as they disrupt people's enjoyment of the outdoors (Beggs, 2000). Furthermore they can also inflict dangerous stings (McGain et al., 2000). Most serious reactions to wasp stings are allergic in nature, so that only a small percentage of the human population is at risk. The severe allergic reaction (called anaphylactic shock) can be fatal unless treated promptly.

The main goals of this paper are to determine the phenology and the duration of wasp flight periods during the last three decades, identify potential links to meteorological factors such as temperature and rainfall, and discuss observed changes of importance to human society.

\section{MATERIAL AND METHODS}

\section{Study area and wasp counts}

The research on social wasps in the agricultural landscape of Kujawy $\left(52.5^{\circ} \mathrm{N}, 18.7^{\circ} \mathrm{E}\right)$ was conducted in the vicinity of Strzelno ca. $20 \mathrm{~km}$ south of the town of Inowrocław from April to October in 1981-2009. During this research, observations and capture of wasps were carried out along transects of 4-6 km length running through the study area. Transects were representative of the hunting territory of Vespula wasps; thus counts of individuals were only made for $V$. germanica. In addition, wasp nests were observed, especially those of $V$. crabro. Visits to the study area were made once in each 2-3 day interval during April-May and in each 5 day interval during June-October, between 10:00-17:00 local time. Visits were only made during optimal weather conditions for wasp flight; sunny, air temperature of $15-25^{\circ} \mathrm{C}$. All wasp individuals were registered along the transects together with a record of their activity, i.e. searching for food, hunting, collection of nectar and honeydew (mainly on plants of Umbelliferae and thickets of Symphoricarpos albus), collection of nest building material (particularly from wooden buildings). Special attention was paid to those parts of the transects with carbohydrate sources, like gardens, orchards, utility buildings as well as service and trade buildings.

All transects were done by the same people, well trained in wasp identification (TP \& KP). More information on the study area, structure and local wasp community are given in separate publications (Pawlikowski, 1990; Pawlikowski \& Pawlikowski, 2006).
Climate variables were taken from the Meteorological Station in Inowrocław ca. $20 \mathrm{~km}$ from the study area. Data were abstracted for monthly mean air temperature and total monthly precipitation. We also examined the potential effect of the North Atlantic Oscillation (NAO; Stenseth et al., 2003), which is derived from a standardised pressure difference between the Azores and Iceland. A winter index was calculated as the mean of monthly values for December-March (values taken from: www.cgd.ucar.edu/cas/jhurrell/indices.html). A high value is indicative of milder and wetter winter weather and has proved useful in other studies (e.g. Stenseth et al., 2003).

\section{Statistical analysis}

Information on wasp flight activity for each year were expressed as Julian date (days after December 31) and derived from field records as follows: date of first queen observed, date of last queen observed, date of first worker observed, beginning and end of the main flight period (from $50 \%$ of all observed workers and first males to $75 \%$ hunting workers). Based on this field data the following measures were also calculated: duration of queen flight (difference in days between the first and the last queen observed), queen mid-date (average of first and last dates), duration of main flight (last minus first) and main flight mid-date (average of first and last dates).

An abundance index, the mean number of individuals observed during $30 \mathrm{~min}$ of transect walk, was used as a potential covariate for $V$. germanica analysis. Equivalent data were not available for $V$. crabro.

Trends in phenology were assessed by regression on year to examine for changes over time. Relationships between phenology and climate variables (monthly mean temperatures, monthly total precipitation, NAO winter index) were examined using correlations, excluding those months that occurred after the mean date of the event.

Sample size differed a little between variables, because not all information was collected every year. All statistical analyses were conducted using the MINITAB v.14 package with $p=0.05$ used as a threshold for significance testing.

\section{RESULTS}

\section{Trends in time}

There were no significant trends in the timing of the first or last queen in either $V$. germanica or $V$. crabro. The duration (last minus first) of queen flight in $V$. germanica had become significantly shorter $(p=0.030$, Table 1) but this was not apparent in $V$. crabro. The first observed worker of $V$. germanica had advanced considerably ( $p<0.001$, Table 1$)$ equating to 26 days earlier over the study period (Fig. 1). Examination of the changes suggests a step-like change after c. 1991. Change in first worker phenology was not apparent in $V$. crabro. There were no significant trends in monthly mean temperatures during the study period (all $p>0.25$ ).

Trends towards an earlier beginning and end of the main flight period were apparent for both species (all $p<$ 0.009; Table 1). However, the beginning and end of the main flight period have advanced more for $V$. germanica (by an estimated 57 and 48 days, respectively) than for $V$. crabro (16 and 19 days, Fig. 2). For $V$. germanica there was also some evidence $(p=0.047)$ of a lengthening of the main flight duration (last minus first).

For the main flight period there was a significant positive correlation between the two species for both begin- 
TABLE 1. A summary of trends in the phenology of Vespula germanica and Vespa crabro. $\mathrm{N}$ indicates the number of years of records. Means are given as both date and day of year together their standard deviation (SD). The trend, significance $(p)$ and $\%$ variation explained $\left(R^{2}\right)$ are derived from regression of the variables on year. Significant results shown in bold.

\begin{tabular}{|c|c|c|c|c|c|c|c|}
\hline Variable & $\mathrm{N}$ & Mean date & Mean & SD & Trend & $p$ & $R^{2}$ \\
\hline \multicolumn{8}{|l|}{ Vespula germanica } \\
\hline Date of first queen & 29 & Apr 26 & 116.8 & 9.4 & 0.211 & 0.323 & 3.6 \\
\hline Date of last queen & 29 & May 30 & 150.8 & 10.9 & -0.379 & 0.118 & 8.8 \\
\hline Date of first worker & 29 & May 25 & 145.2 & 11.5 & -0.906 & 0.000 & 45.3 \\
\hline Beginning of main flight & 29 & Jul 10 & 191.5 & 18.0 & -1.951 & 0.000 & 84.8 \\
\hline End of main flight & 29 & August 25 & 237.7 & 15.7 & -1.643 & 0.000 & 79.2 \\
\hline Duration of queen flight (days) & 29 & & 34.0 & 12.5 & -0.590 & $\mathbf{0 . 0 3 0}$ & 16.2 \\
\hline Duration of main flight (days) & 29 & & 46.2 & 7.1 & 0.307 & 0.047 & 13.8 \\
\hline Queen: mid-date & 29 & May 13 & 133.8 & 8.1 & -0.084 & 0.646 & 0.8 \\
\hline Main flight: mid-date & 29 & August 2 & 214.6 & 16.6 & -1.797 & 0.000 & 85.5 \\
\hline Number per 30 min of transect & 29 & & 6.6 & 4.6 & 0.066 & 0.535 & 1.4 \\
\hline \multicolumn{8}{|l|}{ Vespa crabro } \\
\hline Date of first queen & 22 & May 7 & 127.5 & 5.3 & -0.025 & 0.853 & 0.2 \\
\hline Date of last queen & 19 & June 4 & 155.1 & 11.9 & 0.324 & 0.282 & 6.8 \\
\hline Date of first worker & 19 & June 2 & 153.9 & 8.0 & -0.244 & 0.227 & 8.5 \\
\hline Beginning of main flight & 19 & July 24 & 205.8 & 9.0 & -0.549 & 0.009 & 33.8 \\
\hline End of main flight & 19 & August 22 & 234.5 & 9.1 & -0.663 & 0.001 & 47.9 \\
\hline Duration of queen flight (days) & 19 & & 27.3 & 10.6 & 0.335 & 0.208 & 9.2 \\
\hline Duration of main flight (days) & 19 & & 28.6 & 4.2 & -0.114 & 0.284 & 6.7 \\
\hline Queen: mid-date & 22 & May 19 & 139.3 & 9.0 & 0.070 & 0.758 & 0.5 \\
\hline Main flight: mid-date & 19 & August 8 & 220.2 & 8.8 & -0.606 & 0.002 & 42.9 \\
\hline
\end{tabular}

ning $(r=0.542, p=0.017)$ and end $(r=0.633, p=0.004)$ of the period. Other phenological measures were not significantly correlated between the two species (all $p>$ $0.19)$.

There was no significant trend in the abundance of $V$. germanica $(p=0.535)$. None of the phenological measures appeared to be influenced by the density of $V$. germanica.

\section{Relationship between phenology and climate} variables.

There were surprisingly few significant correlations between the phenological variables and the monthly mean temperatures, monthly total precipitation and the NAO winter index. April temperatures were significantly negatively correlated with the date of the first queen and first

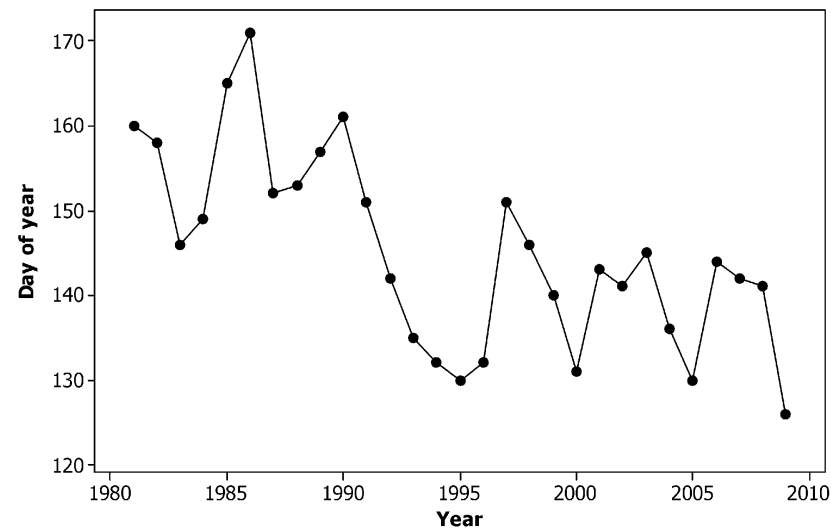

Fig. 1. Trend in the date (day of year) of the first observed worker Vespula germanica in the period 1981-2009.
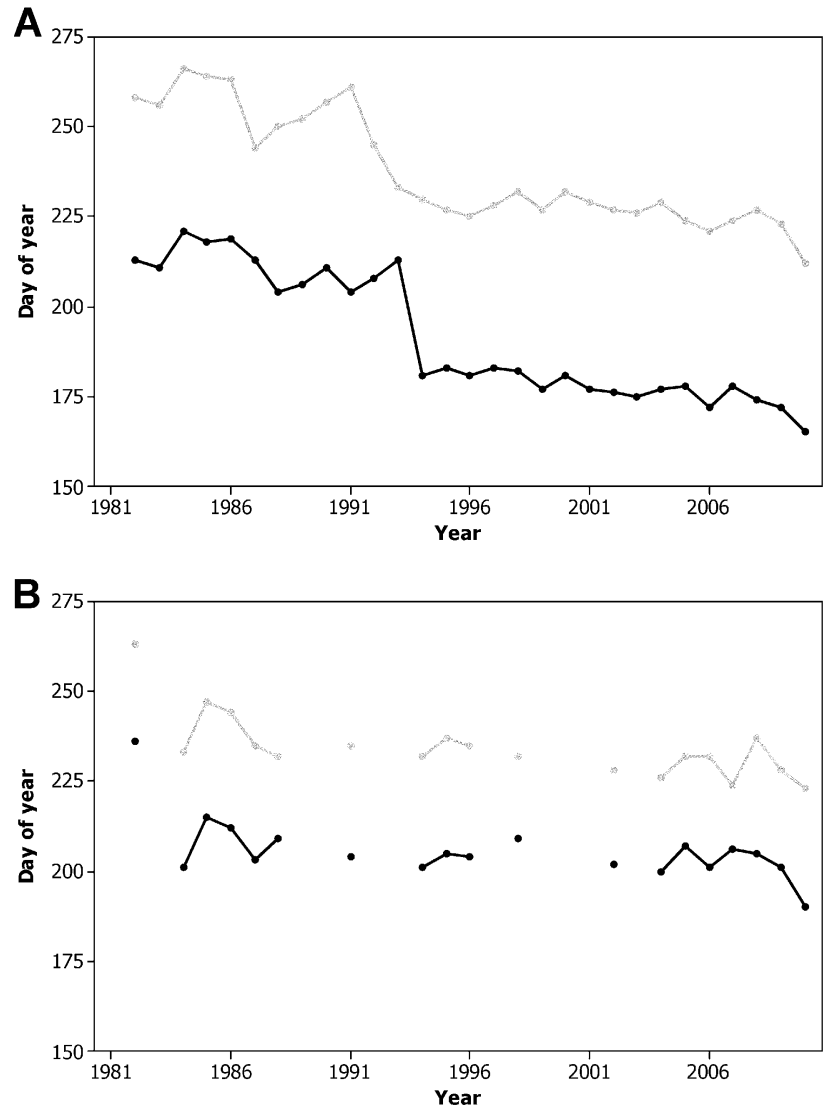

Fig. 2. Change in the main flight period for Vespula germanica (upper) and Vespa crabro (lower). Black and grey lines show start and end of main flight period respectively. Vertical scale identical for the two species. 


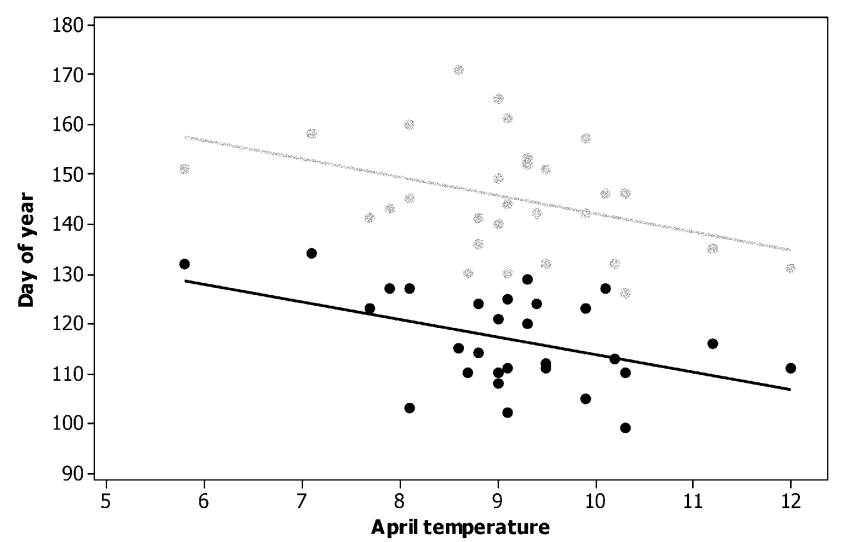

Fig. 3. The relationship between April mean temperature and first observation of queen (black) and worker (grey) Vespula germanica. Regression lines superimposed.

worker $V$. germanica (Fig. 3) and the mean date (average of first and last) of queens for both species. May temperature was significantly negatively correlated with the date of the last queen of $V$. crabro. Precipitation tended to delay phenology, most apparent for April precipitation which was positively correlated (Fig. 4) with dates of first worker, and beginning and end of the main flight periods for $V$. germanica. A few other correlations were significant, but less easy to interpret and all correlations are summarised in Table 2. It should be noted with such a large number of calculated correlations some may have occurred by chance.

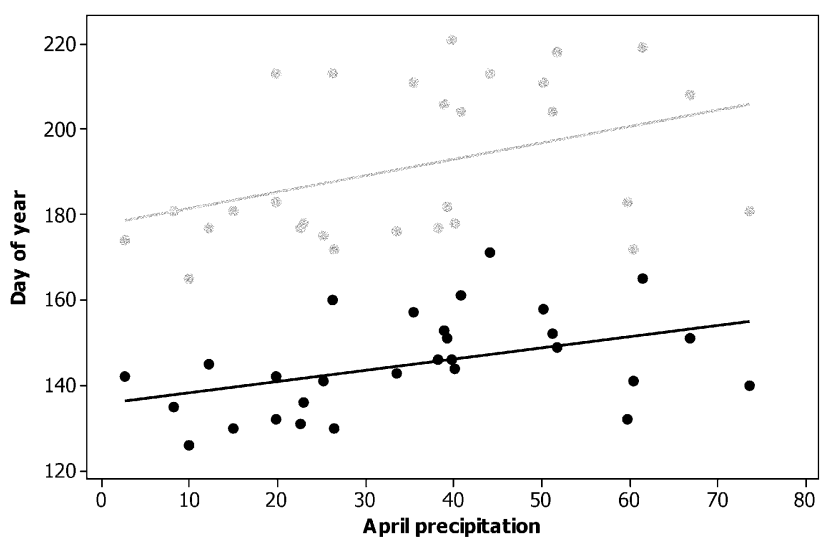

Fig. 4. The relationship between the first observation of worker (black) and main flight period (grey) of Vespula germanica with precipitation $(\mathrm{mm})$ in April. Regression lines superimposed.

\section{DISCUSSION}

To the best of our knowledge, long-term wasp phenology has not previously been studied, however, Visser \& Both (2005) in their review paper suggested changes in wasp phenology in The Netherlands. Moreover they linked this to a potential mismatch with birds like honey buzzard Pernis apivorus feeding on these insects. They even suggested that honey buzzards were recently returning earlier from African wintering grounds, but the peaks of wasp activity had not changed as much, thus

TABLE 2. Correlations between wasp phenology and monthly mean temperature, total monthly precipitation, the North Atlantic Oscillation winter index and the density of Vespula germanica. Significant correlations shown in bold.

\begin{tabular}{|c|c|c|c|c|c|c|c|c|c|c|c|c|c|c|c|c|c|}
\hline \multirow[b]{2}{*}{ Vespula germanica } & \multicolumn{8}{|c|}{ Mean monthly temperature } & \multicolumn{8}{|c|}{ Total monthly precipitation } & \multirow{2}{*}{$\overline{\mathrm{O}} \begin{array}{l}\text { Den- } \\
\text { sity }\end{array}$} \\
\hline & $\mathrm{J}$ & $\mathrm{F}$ & $\mathrm{M}$ & $\mathrm{A}$ & $\mathrm{M}$ & $\mathrm{J}$ & $\mathrm{J}$ & A & $\mathrm{J}$ & $\mathrm{F}$ & $\mathrm{M}$ & $\mathrm{A}$ & $\mathrm{M}$ & $\mathrm{J}$ & $\mathrm{J}$ & A & \\
\hline Date of first queen & -0.09 & 0.10 & -0.26 & -0.45 & & & & & 0.15 & 0.02 & -0.07 & 0.08 & & & & & $-0.29 \quad 0.25$ \\
\hline Date of last queen & -0.14 & -0.17 & 0.16 & $-0.31-$ & -0.02 & & & & 0.07 & -0.21 & 0.19 & 0.23 & 0.00 & & & & $0.05-0.12$ \\
\hline Date of first worker & -0.12 & -0.20 & 0.26 & -0.38 & 0.34 & & & & 0.06 & -0.06 & 0.05 & 0.43 & -0.25 & & & & $0.05 \quad 0.06$ \\
\hline Beginning of main flight & 0.01 & -0.23 & 0.27 & -0.03 & 0.28 & 0.13 & 0.10 & & 0.20 & 0.05 & 0.21 & 0.40 & -0.01 & 0.16 & -0.04 & & $0.25-0.05$ \\
\hline End of main flight & 0.04 & -0.12 & 0.31 & -0.07 & 0.32 & $-0.01-$ & -0.06 & 0.11 & 0.24 & 0.06 & 0.11 & 0.42 & -0.11 & 0.18 & 0.03 & 0.04 & $0.27-0.14$ \\
\hline $\begin{array}{l}\text { Duration of queen flight } \\
\text { (days) }\end{array}$ & -0.05 & -0.22 & 0.34 & 0.07 & -0.05 & & & & -0.05 & -0.20 & 0.22 & 0.14 & 0.31 & & & & $0.26-0.29$ \\
\hline $\begin{array}{l}\text { Duration of main flight } \\
\text { (days) }\end{array}$ & 0.06 & $0.32-$ & -0.01 & -0.0 & $-0.01-$ & -0.3 & -0.3 & -0.45 & 0.04 & 0.00 & -0.30 & -0.08 & -0.22 & -0.01 & 0.16 & 0.07 & -0.0 \\
\hline mid-date & -0.15 & $-0.06-$ & -0.05 & -0.47 & 0.01 & & & & 0.13 & -0.13 & 0.09 & 0.20 & -0.24 & & & & -0.130 .06 \\
\hline ht: mid-date & 0.02 & -0.18 & 0.30 & -0.05 & 0.31 & 0.07 & 0.03 & 0.20 & 0.22 & 0.06 & 0.17 & 0.42 & -0.06 & 0.17 & -0.01 & 0.02 & $0.27-0.10$ \\
\hline $\begin{array}{l}\text { Number per } 30 \mathrm{~min} \text { of } \\
\text { transect }\end{array}$ & 0.0 & 0.15 & 0.04 & -0.09 & 0.13 & 0.2 & 7 & 0.14 & 0 & -0.03 & D. & 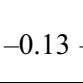 & -0.13 & 27 & - & 2 & -0 . \\
\hline \multicolumn{18}{|l|}{ Vespa crabro } \\
\hline ate of firs & -0.26 & 0.04 & 0.22 & -0.35 & -0.24 & & & & -0.20 & 0.07 & -0.09 & 0.10 & 0.07 & & & & -0.32 \\
\hline Dat & -0.03 & $-0.18-$ & -0.42 & -0.16 & -0.46 & -0.11 & & & 0.10 & -0.29 & 0.04 & -0.20 & 0.29 & -0.53 & & & -0.39 \\
\hline Date of first worker & -0.26 & 0.00 & 0.09 & $-0.30-$ & $-0.01-$ & -0.07 & & & -0.26 & 0.01 & 0.60 & -0.03 & 0.18 & 0.00 & & & -0.16 \\
\hline Beginning of main $\mathrm{fl}$ & -0.19 & 0.00 & 0.16 & -0.30 & 0.17 & $0.05-$ & -0.30 & & -0.05 & 0.03 & 0.60 & 0.22 & 0.07 & 0.05 & 0.63 & & 0.07 \\
\hline End of main flight & 0.09 & -0.06 & 0.37 & -0.07 & 0.32 & $-0.02-$ & $-0.34-$ & -0.01 & 0.13 & 0.08 & 0.67 & 0.17 & 0.24 & 0.18 & 0.54 & -0.07 & 0.32 \\
\hline $\begin{array}{l}\text { Duration of queen flight } \\
\text { (days) }\end{array}$ & $0.11-$ & -0.25 & -0.37 & -0.02 & -0.41 & 0.02 & & & 0.24 & -0.35 & 0.08 & -0.27 & 0.26 & -0.53 & & & -0.29 \\
\hline $\begin{array}{l}\text { Duration of main flight } \\
\text { (days) }\end{array}$ & 0.59 & -0.13 & 0.46 & 0.49 & 0.33 & -0.15 & -0.09 & 0.30 & 0.37 & 0.12 & 0.17 & -0.11 & 0.36 & 0.29 & -0.18 & -0.34 & 0.54 \\
\hline Queen: mid-date & -0.18 & $-0.24-$ & -0.38 & -0.43 & -0.36 & & & & 0.05 & -0.19 & -0.17 & -0.18 & 0.26 & & & & -0.41 \\
\hline Main flight: mid-date & -0.05 & -0.03 & 0.28 & -0.19 & 0.25 & $0.02-$ & $-0.33-$ & -0.08 & 0.04 & 0.05 & 0.66 & 0.20 & 0.16 & 0.12 & 0.60 & 0.01 & 0.20 \\
\hline
\end{tabular}


buzzards have a problem with finding good food sources. Therefore, knowledge on wasp phenology is also interesting from this perspective.

In the years 1981-2009 some aspects of the phenology of the two wasp species Vespula germanica and Vespa crabro have advanced. This is in agreement with predictions suggested by recent rapid climate change and has been described for many organisms (reviews in: Hughes, 2000; Sparks \& Menzel, 2002; Walther et al., 2002; Parmesan \& Yohe, 2003; Voigt et al., 2003; Badeck et al., 2004) including different groups of insects (Parmesan et al., 1999; Hickling et al., 2005). This study revealed an advance in the main flight activity of workers of both studied wasps apparently driven, at least partly, by temperature. This relationship is only conclusively demonstrated in $V$. germanica and may reflect the much greater abundance, and hence more reliable observations, of this species. The relationships with temperature appear less clear than those found for similar insects, such as the honey bee Apis melifera (Gordo \& Sanz, 2006). We believe that wasps may not be so strongly related to temperature for several reasons.

Firstly, Spiewok \& Schmolz (2006) showed that ambient temperature and light intensity have an influence on the flight performance of wasps, especially hornets. Moreover, the regulation of flight speed in different environmental conditions is sex specific (in wasps this equates to differences between queens and workers). The authors hypothesized that the reasons for these differences may lie in sex-specific cooling mechanisms; workers might regulate their body temperature through forced heat loss, whereas males, first appearing at the beginning of the main flight period, might reduce their heat production rates. Therefore, they may react in a different way to temperature across the season (Archer, 1998). We also believe that this fact may help to explain why in our study queens and workers responded differently to temperature.

Secondly, unlike in specialised predator/herbivore systems our studied wasp species may be less vulnerable to temperature increases advancing organisms lower in the trophic pyramid (e.g. flies, nectar-rich plants). An example where climate change might not lead to mistiming is the orange tip butterfly (Anthocharis cardamines) because its mean date of first appearance has a very similar response to March temperatures as the flowering date of garlic mustard (Alliaria petiolata), one of its host plants (Sparks \& Yates, 1997; Harrington et al., 1999). However, on the other hand there are examples of mismatch, for example winter moth Operophtera brumata egg hatch phenology has clearly advanced more over the past 15 years in The Netherlands than oak Quercus spp bud burst phenology has advanced (Visser \& Both, 2005). This is easy to understand in a simple system, like a specialized predator/herbivore focussing on one particular prey, but wasps may choose different food, probably in relation to availability and local environmental conditions (Edwards, 1980; Kemper \& Döhring, 1967). Therefore, they may switch to different food sources (Heinrich, 1993) depending on current temperature. However, the advances in some aspects of wasp phenology are so great that potential conflicts with early season adverse weather conditions need to be considered.

In this paper we have shown an advance of the main flight period of both studied wasp species and a relationship between phenology and temperature (particularly that in April) for $V$. germanica. $V$. germanica flight appears to be more closely correlated with temperature than that of $V$. crabro and this may explain the greater variability in observation dates of $V$. germanica compared to those of $V$. crabro. Moreover, $V$. germanica is a smaller species with less varied food sources compared to $V$. crabro, so its sensitivity to temperature should be greater (Heinrich, 1993). Other studies have reported temperature response in insect migration timing (e.g. Kullberg, 1995), population structure (e.g. Fordham et al., 1991), larval development rates (Archer, 1998) and changes in distribution (e.g. Spradbery \& Maywald, 1992).

Some aspects of the phenology of the wasps studied changed dramatically despite no significant changes in monthly mean air temperature during the study period at the local Met Station. We have not been able to fully explain the magnitude of change and suggest that further study is necessary if more detailed weather variables become available. Variables such as frost and rainfall frequency, sunshine or maximum temperature may be more important than those that we had access to. Furthermore it may be that the wasps are having to "catch-up" with earlier advances in flower and prey phenology and that their response to temperature is indirect and delayed. Climate change is likely to affect many aspects of the life cycles of wasps and as a consequence the resulting potential conflicts between them needs to be investigated.

ACKNOWLEDGEMENTS. We are grateful to K. Kujawa for assistance with obtaining temperature data, and two anonymous referees for their comments on an earlier version. The final analysis of data was supported by a small grant project from the City of Poznań (to PT and WB-C, Ro M.V./34-20).

\section{REFERENCES}

Archer M.E. 1998: A lifetime with wasps (Hymenoptera: Vespinae). Naturalist 123: 3-14.

Badeck F.W., Bondeau A., Böttcher K., Doctor D. \& Lucht W. 2004: Responses of spring phenology to climate change. New Phytol. 162: 295-309.

Bale J.S., Masters G.J., Hodkinson I.D., Awmack C., Bezemer T.M., Brown V.K., Butterfield J., Coulson J.C., Farrar J., Good J.G., Harrington R., Hartley S.E., Jones T.H., LinDroth R.L., Press M.C., Syrmnioudis I., Watt A.D. \& WhitTAKER J.B. 2002: Herbivory in global climate change research: direct effects of rising temperature on incect herbivores. Glob. Change Biol. 8: 1-16.

BEGGS J.R. 2000: Impact and control of introduced Vespula wasps in New Zealand. In Austin A.D. \& Dowton M. (eds): Hymenoptera: Evolution, Biodiversity and Biological Control. CSIRO Publishing, Collingwood, pp. 404-409.

Dell D., Sparks T.H. \& DenNis R.L.H. 2005: Climate change and the effect of increasing spring temperatures on emergence 
dates of the butterfly Apatura iris (Lepidoptera: Nymphalidae). Eur. J. Entomol. 102: 161-167.

Dor H. 2008: Delayed phenological timing of dragonfly emergence in Japan over five decades. Biol. Lett. 4: 388-391.

Edwards R. 1980: Social Wasps. Their Biology and Control. Rentokil, East Grinstead, 398 pp.

Fordham R.A., Craven A.J. \& Minot E.O. 1991: Phenology and population structure of annual nests of the German wasp Vespula germanica (Fab.) in Manawatu, New Zealand, with particular reference to late summer and autumn. N.Z. J. Zool. 18: $127-137$.

GoRdo O. \& SANZ J.J. 2006: Temporal trends in phenology of the honey bee Apis mellifera (L.) and the small white Pieris rapae (L.) in the Iberian Peninsula (1952-2004). Ecol. Entomol. 31: 261-268.

Harrington R., Woiwod I.P. \& Sparks T.H. 1999: Climate change and trophic interactions. Trends Ecol. Evol. 14: 146-150.

Harrington R., Clark S.J., Welham S.J., Verrier P.J., Denholm C.H., Hulle M., Maurice D., Rounsevell M.D., Cocu N. \& EUROPEAN UNION EXAMINE CONSORTIUM. 2007: Environmental change and the phenology of European aphids. Glob. Change Biol. 13: 1550-1564.

Hassall C., Thompson D.J., French G.C. \& Harvey I.F. 2007: Historical changes in the phenology of British Odonata are related to climate. Glob. Change Biol. 13: 933-941.

HeInRICH B. 1993: The Hot-Blooded Insects - Strategies and Mechanisms of Thermoregulation. Springer, Berlin-Budapest, $601 \mathrm{pp}$.

Hickling R., Roy D.B., Hill J.K. \& Thomas C.D. 2005: A northward shift of range margins in British Odonata. Glob. Change Biol. 11: 502-506.

HugHeS L. 2000: Biological consequences of global warming. Is the signal already apparent? Trends Ecol. Evol. 15: 56-61.

Kemper H. \& DöHring E. 1967: Die sozialen Faltenwespen Mitteleuropas. Paul Parey, Berlin-Hamburg, 180 pp.

Konvicka M., Maradova M., Benes J., Fric Z. \& Kepka P. 2003: Uphill shifts in distribution of butterflies in the Czech Republic: effects of changing climate detected on a regional scale. Glob. Ecol. Biogeogr. 12: 403-410.

KUllberg J. 1995: Migration of hornet (Vespa crabro L.) in southwestern archipelago of Finland in 1992. Sahlbergia 2: 112.

Le Conte Y. \& Navajas M. 2008: Climate change: impact on honey bee populations and diseases. Rev. Sci. Tech. Int. Epiz. 2: 499-510.

Matsuura M. \& Yamane S. 1984: Biology of the Vespine Wasps. Springer, Berlin-Hong Kong, 323 pp.

Mauss V. 2008: Bionomics and defensive behaviour of bees and diplopterous wasps (Hymenoptera, Apidae, Vespidae) causing venom allergies in Germany. Hauarzt 59: 184.

McGain F., Harrison J. \& Winkel K.D. 2000: Wasp sting mortality in Australia. Med. J. Australia 173: 198-200.

Moller H., Tilley J.A.V., Plunkett G.M. \& Clapperton B.K. 1991: Nest sites of common and German wasps (Hymenoptera: Vespidae). N.Z. J. Zool. 8: 1-125.

Nadolski J., Majczyna D., Loga B. \& Stańczyk-Lutz A. 2000: Hornet (Vespa crabro) in Łódź, preliminary estimate of epidemiology. Acta Univ. Lodz. Folia Zool. 4: 47-56.
Parmesan C. \& Yohe G. 2003: A globally coherent fingerprint of climate change impacts across natural systems. Nature 421: $37-42$.

Parmesan C., Ryrholm N., Stefanescu C., Hill J.K. \& Thomas C.D. 1999: Poleward shifts in geographical ranges of butterfly species associated with regional warming. Nature 399: 579-583.

Pawlikowski T. 1990: Wasp communities (Hymenoptera, Vespidae) in the agricultural landscape of Chelmno Land (N Poland). Pol. Pismo Entomol. 60: 115-128.

Pawlikowski T. \& Pawlikowski K. 2006: Long-term dynamics of structure changes of the social wasp community (Hymenoptera: Vespinae) in agricultural landscape of the Kujawy region. Ecol. Quest. 7: 21-28.

Roy D.B. \& Sparks T.H. 2000: Phenology of British butterflies and climate change. Glob. Change Biol. 6: 407-416.

SPARKS T.H. \& YATES T.J. 1997: The effect of spring temperature on the appearance dates of British butterflies 1883-1993. Ecography 20: 368-374.

Sparks T.H. \& Menzel A. 2002: Observed changes in seasons, an overview. Int. J. Climatol. 22: 1715-1722.

Sparks T.H., Dennis R.L.H., Croxton P.J. \& Cade M. 2007: Increased migration of Lepidoptera linked to climate change. Eur. J. Entomol. 104: 139-143.

SPIEwOK S. \& Schmolz E. 2006: Changes in temperature and light alter the flight speed of hornets (Vespa crabro L.). Physiol. Biochem. Zool. 79: 188-193.

SpradBery J.P. 1973: Wasps: An Account of the Biology and Natural History of Solitary and Social Wasps. Sigwick and Jackson, London, xvi + 408 pp.

Spradbery J.P. \& Maywald G.F. 1992: The distribution of the European or German wasp, Vespula germanica (F) (Hymenoptera, Vespidae), in Australia - past, present and future. Austral. J. Zool. 40: 495-510.

Stenseth N.C., Ottersen G., Hurrell J.W., Mysterud A., Lima M., Chan K.S., Yoccoz N.G. \& AdLAndsvik B. 2003: Studying climate effects on ecology through the use of climate indices: the North Atlantic Oscillation, El Nino Southern Oscillation and beyond. Proc. R. Soc. Lond. (B) 270: 2087-2096.

Visser M.E. \& Bотн C. 2005: Shifts in phenology due to global climate change: the need for a yardstick. Proc. R. Soc. Lond. (B) 272: 2561-2569.

Voight W., Perner J., Davis A.J., Eggers T., Schumacher J., Bährmann R., Fabian B., Heinrich W., Köhler G., Lichter D., Marstaller R. \& Sander F.W. 2003: Trophic levels are differentially sensitive to climate. Ecology 84: 2444-2453.

Walther G.R., Post E., Convey P., Menzel A. \& Parmesan C. 2002: Ecological responses to recent climate change. Nature 416: 389-195.

Warren M.S., Hill J.K., Thomas J.A., Asher J., Fox R., Huntley B., Roy D.B., Telfer M.G., Jeffcoat E.S., Harding P., Jeffcoate J., Willis S.G., Greatorex-Davies J.N., Moss D. \& Thоmas C.D. 2001: Rapid responses of British butterflies to opposing forces of climate and habit at change. Nature 414: 65-69.

Received October 26, 2009; revised and accepted December 17, 2009 